\title{
Carcinosarcoma of the breast with massive osseous malignant component: a basal-like entity with myoepithelial differentiation
}

\section{Carcinosarcom mamar cu componentă osoasă masivă - entitate basal-like cu diferențiere mioepitelială}

\author{
Cristina Marian $^{1 *}$, Daniela Soanca ${ }^{1}$, Szabo Kinga ${ }^{1}$, Monica Boros ${ }^{2}$, Simona Stolnicu ${ }^{1}$ \\ 1. Department of Pathology, University of Medicine and Pharmacy Târgu Mureş, România \\ 2. Department of Pathology, Clinical Obstetrics and Gynecological Hospital Oradea, România
}

\begin{abstract}
We present the case of a 77 year old patient with a primary breast carcinosarcoma composed mostly of an osteogenic sarcoma of fibroblastic type in which only immunohistochemical analysis disclosed the presence of a minor malignant epithelial component. The malignant mesenchymal component derives from dedifferentiation of myoepithelial cells since myoepithelial markers are positive. Also, like the majority of the other metaplastic carcinomas in the breast, carcinosarcoma is a basal type of tumor that will not respond to endocrine drugs or Her2/neu therapy.
\end{abstract}

Keywords: carcinosarcoma, osseous differentiation, basal-like, myoepithelial differentiation

\section{Rezumat}

Prezentăm cazul unei paciente de 77 de ani cu o formațiune mamară primară constituită predominant dintr-o componentă sarcomatoasă osteogenică de tip fibroblastic. Diagnosticul final de carcinosarcom mamar s-a stabilit pe baza examinărilor imunohistochimice, care au evidențiat prezența unei componente minore epiteliale maligne. Componenta malignă mezenchimală, pozitivă la marcheri mioepiteliali s-a dezvoltat prin dediferențierea celulelor mioepiteliale. Precum majoritatea carcinoamelor mamare de tip metaplastic, carcinosarcomul reprezintă o tumoră de tip bazal, care nu raspunde la tratamentul endocrin sau la Herceptin.

Cuvinte cheie: carcinosarcom, diferențiere osoasă, basal-like, diferențiere mioepitelială

Received: $16^{h}$ August 2012; Accepted: $20^{\text {th }}$ January 2013; Published: 31 $1^{\text {st }}$ January 2013.

\footnotetext{
*Corresponding author : Dr. Cristina Marian, Department of Pathology, Emergency County Hospital Târgu Mureş, Str. Gh. Marinescu nr. 50, E-mail: cristinasarghe@yahoo.com
} 


\section{Introduction}

Metaplastic carcinoma of the breast is a relatively rare type of breast cancer (less than 1\%) that encompasses a heterogeneous group of breast carcinoma characterized by cancer cells displaying differentiation toward epithelial (squamous) or mesenchymal elements like spindle, chondroid, osseous and rhabdoid cells (1). Cartilaginous and/or osseous metaplasias are exceptionally rare, occurring in $0.003-0.12 \%$ of cases $(2,3)$. Osseous differentiation can have either benign or malignant features. Carcinoma with malignant osseous differentiation is considered to be a carcinosarcoma. When the osseous metaplasia has a malignant morphology and occupies almost the entire lesion, the microscopic diagnosis of a carcinosarcoma and the differentiation from a primary mammary sarcoma can be very difficult. We present a case of carcinosarcoma with massive osseous differentiation mimicking a primary osteosarcoma of the breast, which was also triple negative (ER, PR and Her2/neu) and positive for basal cell-type of cytokeratins and myoepithelial markers indicating that this subtype is a particular variant of tumor which should have a different treatment.

\section{Case report}

A 77-year-old woman with no history of previous breast surgery or radiotherapy was admitted to the Surgical Department for a $3 \mathrm{~cm}$ diameter palpable mass in the superior-exterior quadrant of the left breast which was diagnosed as malignant at the intraoperatory examination. The patient underwent total mastectomy and axillary lymph node dissection. Gross examination of the specimen revealed an ill-defined solid mass of $28 \mathrm{~mm}$ diameter, gray-to-tan in color, with patchy areas of gritty, hard tissue and on cut surface with focal hemorrhage and necrosis. No areas of phyllodes tumor have been observed within the tumor (Figure 1).

Microscopically, the tumor was composed of a high grade osteogenic sarcoma of fibroblastic type. The tumor cells arranged in fascicles were spindle or polygonal in shape, with marked atypical nuclei and frequent mitotic figures (41 mitoses/10HPF). These areas are admixed with variable areas of osteoid formation, necrosis and hemorrhage (Figures 2, 3). No areas of classic infiltrating ductal carcinoma were observed on careful examination of the 4 sections from the tumor; multiple ducts with high grade in situ ductal carcinoma were seen at the periphery of the tumor or entrapped within the tumor (Figure 4A). The tumor had pushing-type of margins at the periphery and no tumor emboli were seen adjacent to the tumor.

Immunohistochemically, the sarcomatous tumor cells were diffusely positive for Vimentin (Dako, prediluted), Osteopontin (Dako, prediluted), CD 56 (Dako, prediluted), EGFR (human epidermal growth factor receptor) (Dako, prediluted) and the ki 67 (Dako, prediluted) index was $90 \%$ but these cells were negative for ER, PR and Her2/neu (all markers Dako, prediluted) (Figure $4 B-C$ ). They were also negative for CD 34, Synaptophisin and S-100 protein (all markers Dako, prediluted). However, the sarcomatous component was focally positive for basal cell-type cytokeratins (CK) as CK 34betaE12, CK17 and CK5/6 and diffuse positive for myoepithelial markers such as p63, Actin and CD 10 (al markers Dako, prediluted) (Figures 4D- F, 5A-C). Those minor areas that were positive for basal- cell-type CK were also positive for AE1/AE3 and E-Cadherin (Dako, prediluted) highlighting the infiltrating carcinomatous component of ductal type, with a squamoid appearance (Figure 5D-F). These minor carcinomatous foci were negative for ER, PR and HER2/neu and ki67 index was $80 \%$. Also, this second component was negative for Vimentin but focally positive for CD 10 (Table 1). Due to the presence of malignant mesenchymal component associated with a minor malignant epithelial component a diagnosis of high grade carcinosarcoma with basal-like and myoepithelial differentiation, associated with high grade in situ carcinoma was established. 10 axillary lymph nodes 


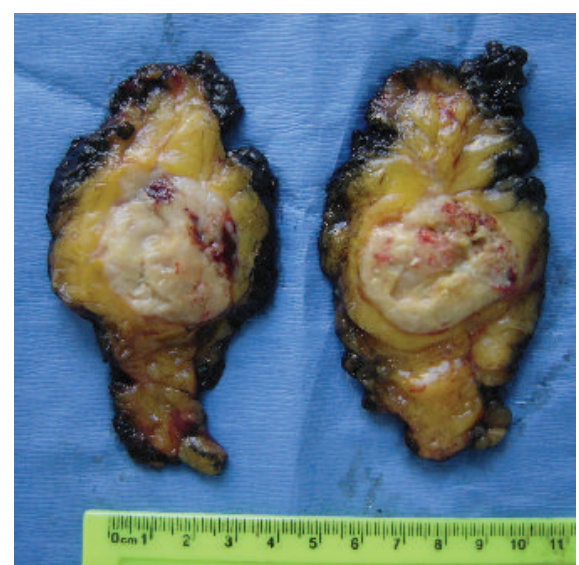

Figure 1. Solid mass of 28mm diameter, gray-to-tan in color, with focal necrosis and pushing-type margins

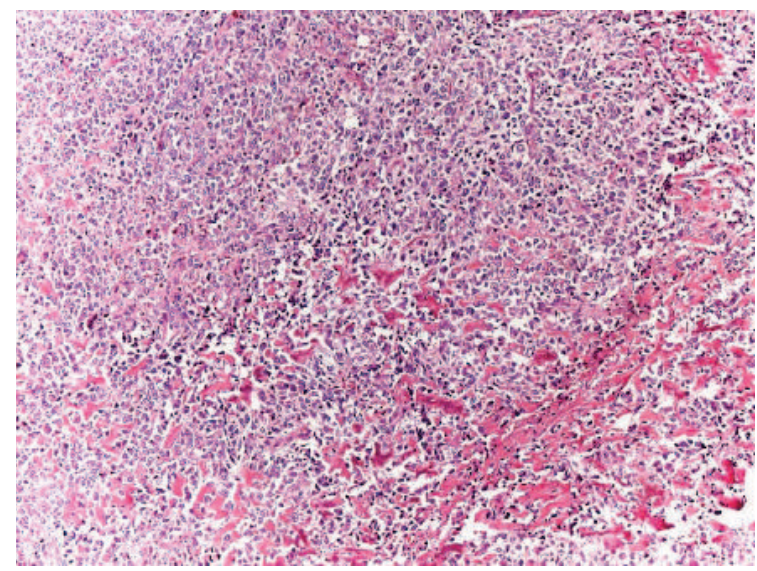

Figure 3. Tumor cells with spindle or polygonal shape, atypical nuclei and frequent mitotic

figures, H-E, 20X

were negative for metastatic carcinoma. The patient underwent radiotherapy and 6 month after the surgery she developed multiple osseous metastases. Due to the age of the patient no other treatment was indicated and she is still alive 2 years after the initial diagnosis with metastatic disease but no sign of local recurrences.

\section{Discussion}

Metaplastic carcinoma is a general term referring to a heterogeneous group of breast tumors characterized by an intimate admixture of

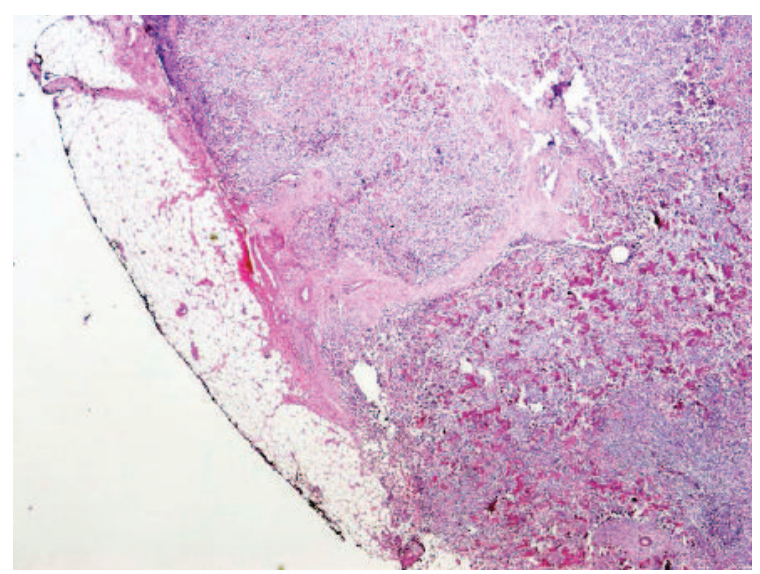

Figure 2. Solid proliferation of spindle tumor cells admixed with osteoid formation $4 \mathrm{X}, \mathrm{H}-\mathrm{E}$

adenocarcinoma with dominant areas of spindle cell, squamous, osseous or chondroid differentiation $(1,4,5)$. Although the most commonly encountered heterologous elements in mammary gland are bone and cartilage, invasive breast cancer with cartilaginous or osseous metaplasia is rare, with a reported frequency of $0.003-0.12 \%$ $(2,3)$. Osseous metaplasia may have either a benign pattern or a malignant one. Most of these tumors contain benign areas of bone formation within otherwise typical carcinoma; a zone of reactive stromal cells often separates the carcinoma from the bone (6). The rare examples of such tumors that have been studied in detail in electron microscopy show no evidence of epithelial transformation of the osseous component and do not express cytokeratin suggesting that these areas may develop from stromal cells (7). The presence of areas of benign osseous differentiation does not change the prognosis of a not otherwise specified infiltrating ductal carcinoma; some of the papers reported a better prognosis of these lesions (8).

When the areas of osseous differentiation are malignant and admixed with areas of carcinoma, a diagnosis of carcinosarcoma is recommended and this tumor should be distinguished from carcinomas displaying mature bone (9). In carcinosarcoma the areas of malignant bone differentiation do not express epithelial markers. 

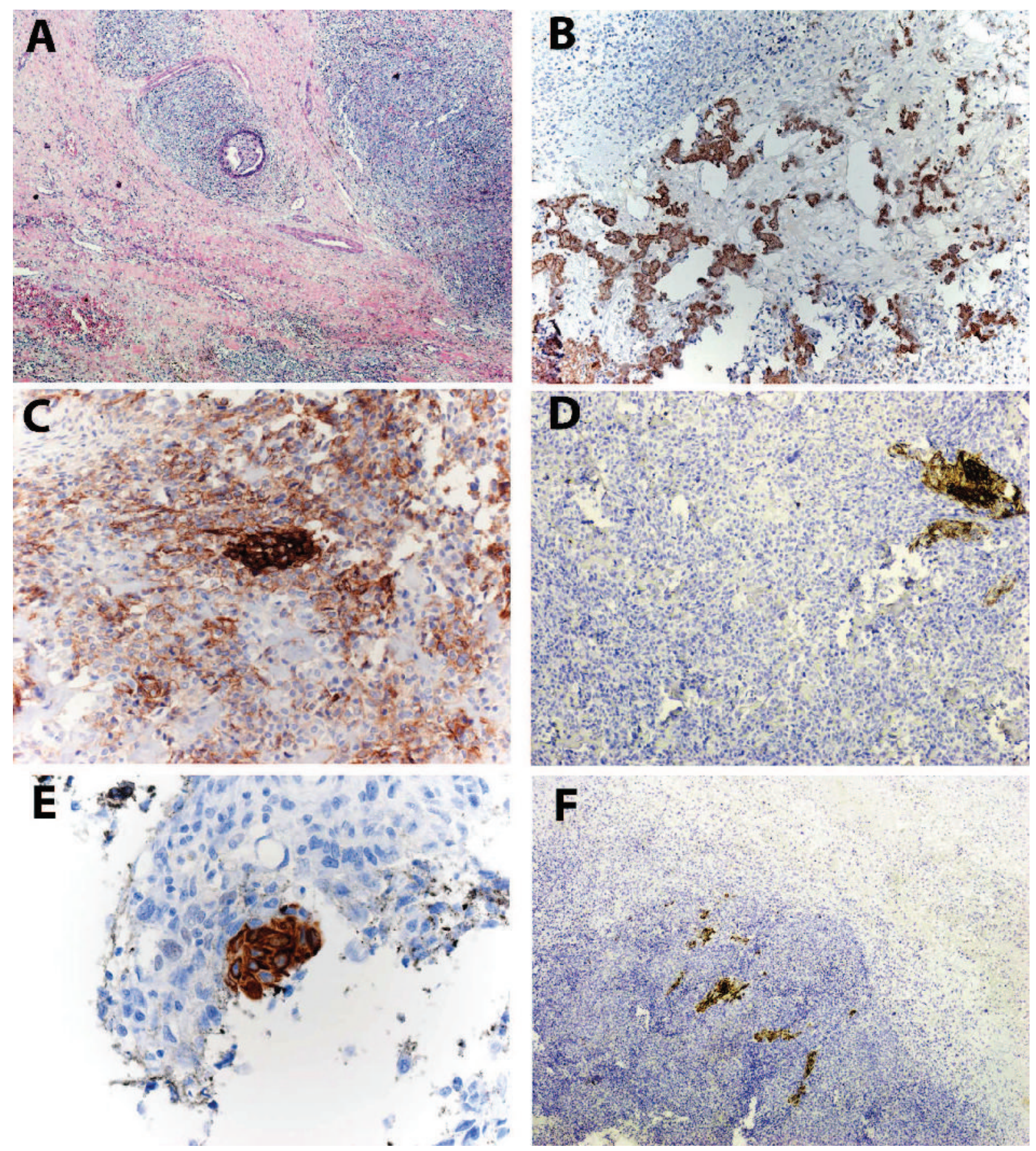

Figure 4. A. Ducts with high grade in situ ductal carcinoma are entrapped within the tumor, H-E, 10X. B. The tumor cells in the sarcomatous component are positive for Osteopontin, 20X, and for EGFR. 20X (C.) Focal positivity for CK34betaE12, 20X (D). E. for CK 5/6, 20X. F. and for CK 17 indicating areas of minor carcinomatous component, $4 \mathrm{X}$. 

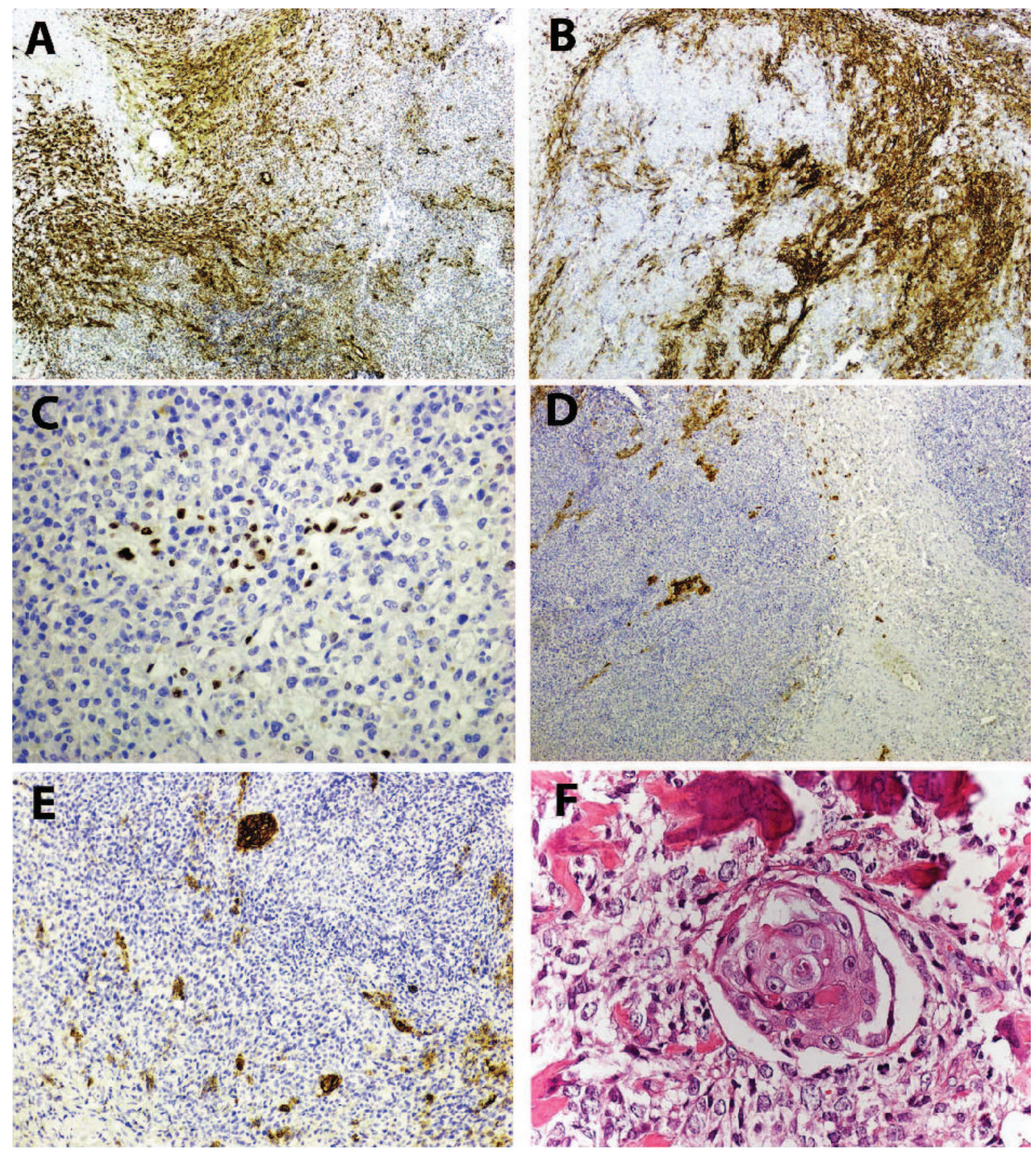

Figure 5. A. Difuse positivity for Actin in the sarcomatous component, $4 \mathrm{X}$. B. Positivity for CD 10 of the sarcomatous component, 4X. C. P63 was focally positive in the malignant mesenchimal component, 20X. D. The epithelial component was highlighted by the focal positivity for AE1/AE3, 4X. E. The minor epithelial malignant component was positive for E-Cadherin suggesting a ductal type, 4X. F. The minor epithelial component has a squamoid appearance on H-E, 40X. 
Table 1. Immunohistochemical analysis of the tissue specimen

\begin{tabular}{|ccc}
\hline Antibody & $\begin{array}{c}\text { Sarcomatous } \\
\text { component }\end{array}$ & $\begin{array}{c}\text { Carcinomatous } \\
\text { component }\end{array}$ \\
\hline CK AE1/AE3 & - & + \\
PR & - & - \\
Ki 67 & - & $80 \%$ \\
HER2/neu & $90 \%$ & Focal + \\
CD 10 & - & - \\
p63 & + & - \\
EGFR & + & Focal + \\
CK 17 & + & - \\
Vimentin & - & - \\
\hline Osteopontin & + & - \\
CD 56 & + & - \\
CD 34 & + & - \\
Synaptophisin & - & - \\
S-100 protein & - & Focal + \\
CK 34betaE12 & - & + \\
E-Cadherin & - & Focal + \\
CK 5/6 & - & - \\
\hline Smooth muscle actin & - & \\
\hline
\end{tabular}

When these areas occupy the majority of the tumor, the microscopic diagnosis is very difficult as this lesion can be misdiagnosed as a primary sarcoma of the breast, especially with osteosarcoma.

Pure primary osteogenic sarcoma of the breast is very rare, more often mammary osteosarcoma is a component of biphasic tumor such as fibroadenoma, phyllodes tumor or carcinosarcoma. In this case, no distinctive areas of infiltrating carcinoma have been noticed on $\mathrm{H}-\mathrm{E}$ sections. On microscopic examination the tumor was composed only of pure osteogenic sarcoma of spindle cell type. However, the immunohistochemical analysis highlighted small areas of panCK (AE1/AE3) positivity as being carcinomatous areas. This, together with the presence of in situ ductal carcinoma at the periphery of the tumor allowed us a correct diagnosis of carcinosarcoma. This is the reason why, it is important that all the breast tumors with massive sarcomatous component should be evaluated on immunohistochemistry for the expression of epithelial antigens. The origin of the sarcomatous component in these tumors has been attributed to the metaplastic potential of the myoepithelial cells (9-11). The focal positivity of both the sarcomatous and carcinomatous component in the present tumor for a variety of myoepithelial markers such as p63, CD 10, Actin in combination with positivity for basal cell-type of CK such as CK 34beta E12, CK 17, CK 5/6 confirms a myoepthelial differentiation. Also, the positivity for such markers confirms the fact that this tumor belongs to the basal-like type of breast carcinomas, same as the metaplastic carcinoma of the breast which has clinical and prognostical implications.

Carcinosarcoma represents a very aggressive tumor with a poorer prognosis than not other- 
wise specified ductal infiltrating carcinoma or metaplastic carcinoma. Especially if this tumor lacks or has only a minimal overt invasive carcinomatous component it will have a biologic behaviour similar to that of sarcomas (12-14). Metaplastic breast carcinomas (including carcinosarcomas - as shown in this case) are commonly negative for HER2/neu and ER, PR which also implies that the treatment for this kind of tumor should be different. These patients should not receive endocrine agents or HER2/neu therapy but a multimodality approach including sarcoma- directed adjuvant chemotherapy and radiotherapy $(1,15-18)$. Also, carcinosarcoma (this case included) as most of the metaplastic carcinomas overexpress EGFR and these patients might benefit from therapies targeting EGFR such as gefitinib and cetuximab (19).

\section{Acknowledgement}

The diagnostic contribution of Professor Francisco F. Nogales, University of Granada Spain is gratefully acknowledged in this case.

\section{References}

1. Moinfar F.: Essentials of diagnostic breast pathologya practical approach. Springer; 2007: 234-236

2. Ninomiya J, Oyama T, Horiguchi J, Koibuchi Y, Yoshida T, Iijima $\mathrm{K}$ et al: Two cases of breast cancer with cartilaginous and osseous metaplasia. Breast Cancer. 2005;12(1):52-6.

3. Kijima Y, Umekita Y, Yoshinaka H, Owaki T, Sakamoto A, Yoshida $\mathrm{H}$ et al: A case of breast carcinoma with cartilaginous and osseous metaplasia. Breast Cancer. 2006;13(2):214-9.

4. Rosen PP.: Rosen's breast pathology. 2nd ed. Philadelphia, PA: Lippincott- Williams\&Wilkins; 2001: 425452

5. Tavassoli FA, Devilee P.: Tumours of the breast and female genital organs. Lyon, France, IARC Press; 2003: p 37-41

6. Tavassoli Fattaneh: Pathology of the breast. HongKong, McGraw-Hill Professional, 1999: p 504
7. An T., Grathwohl M., Frabe W.J.: Breat carcinoma with osseous metaplasia: An electron microscopic study. Am.J.Clin.Pathol., 1984, 81: 127-132

8. Chhieng C, Cranor M, Lesser ME, Rosen PP.: Metaplastic carcinoma of the breast with osteocartilaginous heterologous elements. Am J Surg Pathol. 1998 Feb;22(2):188-94.

9. Tavassoli Fattaneh: Pathology of the breast. HongKong, McGraw-Hill Professional, 1999: p 614

10. Carter MR, Hornick JL, Lester S, Fletcher CD.: Spindle cell (sarcomatoid) carcinoma of the breast: a clinicopathologic and immunohistochemical analysis of 29 cases. Am J Surg Pathol. 2006 Mar;30(3):300-9.

11. Rungta S, Kleer CG.: Metaplastic carcinomas of the breast: diagnostic challenges and new translational insights. Arch Pathol Lab Med. 2012 Aug;136(8):896-900

12. Bae SY, Lee SK, Koo MY, Hur SM, Choi MY, Cho $\mathrm{DH}$ et al: The prognoses of metaplastic breast cancer patients compared to those of triple-negative breast cancer patients. Breast Cancer Res Treat. 2011 Apr;126(2):471-8 13. Davis WG, Hennessy B, Babiera G, Hunt K, Valero V, Buchholz TA et al: Metaplastic sarcomatoid carcinoma of the breast with absent or minimal overt invasive carcinomatous component: a misnomer. Am J Surg Pathol. 2005 Nov;29(11):1456-63.

14. Gibson G.R., Qian D., Ku J.K., et al. Metaplastic breast cancer: clinical features and outcomes, Am. Surg. 71 (2005) 725-730

15. .Weigelt B, Kreike B, Reis-Filho JS.: Metaplastic breast carcinomas are basal-like breast cancers: a genomic profiling analysis. Breast Cancer Res Treat. 2009 Sep;117(2):273-80. Epub 2008 Sep 25.

16. Gutman H, Poouck RE, Janjan NA et al: Biologic distinction and therapeutic implications of sarcomatoid metaplasia of epithelial carcinoma of the breast. J Am Coll Surg. 1995; 180: 193-199

17. Tseng WH, Martinez SR.: Metaplastic breast cancer: to radiate or not to radiate? Ann Surg Oncol. 2011 Jan;18(1):94-103

18. Liedtke C, Mazouni C, Hess KR, André F, Tordai A, Mejia JA et al: Response to neoadjuvant therapy and longterm survival in patients with triple-negative breast cancer. J Clin Oncol. 2008 Mar 10;26(8):1275-81

19. Leibl S., Moinfar F.: Metaplastic breast carcinomas are negative for Her-2 but frequently express EGFR (Her1): potential relevance to adjuvant treatment with EGFR tyrosine kinase inhibitors? J.Clin.Pathol., 2005; 58: 700704 